\title{
SUSCEPTIBILITY OF CUCUMBER VARIETIES TO THE BROAD MITE Polyphagotarsonemus latus (Banks) INFESTATION AND ITS RELATION TO LEAF PHYTOCHEMICAL COMPONENTS. \\ Hassan, M. F.'; M. A. Zaher ${ }^{1}$; M. E. E. El-Nagar ${ }^{2}$ and Enas, M. K. Mostafa ${ }^{2}$ \\ 1- Faculty of Agriculture, Cairo University, Giza, Egypt. \\ 2- Plant Protection Research Institute, Agric. Res. Center, Giza, Egypt.
}

\section{ABSTRACT}

Three cucumber varieties namely Zena, Thamin and Sweet crunch were cultivated during nili 2005 and summer 2006 seasons on the farm of Plant Protection Research Institute, Dokki, Giza to evaluate its susceptibility to the tarsonemid pest $P$.latus infestation. The relationship between the mite different stages populations and some plant leaves phytochemical components were also investigated.

Sweet crunch proved to be the most susceptible variety to mite infestation, while Zena variety was tolerant and Thamin was moderately infested.

The relationship between the population density of P.latus eggs, immatures and adults on the three tested varieties was significantly positive with true protein, but significantly negative with total hydrolysable carbohydrate, total sugars, non- reducing sugars and total phenolic compound. On the other extreme, the relationship was insignificantly negative with phosphorous and potassium elements, but it was insignificantly positive with reducing sugars.

\section{INTRODUCTION}

Cucumber occupies an important position among vegetable crops in Egypt. According to Ministry of Agriculture records of 2005, the cultivated area was 11043 feddans in the open field and $5404924 \mathrm{~m}^{2}$ in plastic houses. Throughout the growing season, the cucumber plants are attacked by some phytophagous mites which cause enormous losses in both open field and plastic houses such as the red spider mite, Tetranychus urticae Koch, and $T$. cucurbitacearum (Sayed) (Tetranychidae) and the broad mite, Polyphagotarsonemus latus (Banks), (Tarsonemidae).

This tarsonemid mite $P$. latus (Banks) is one of the most injurious mites with different common names (yellow, yellow broad, tropical and white cotton or jute mite) (Jeppson et al, 1975, Gerson, 1992 and Masoud et al, 2001). This mite is a minute herbivorous that attacks numerous plant crops belong to different families in tropical and subtropical regions (Gerson, 1992 and Grinberg et al, 2004). Also this mite may act as a vector of leaf curl virus (Chakraborti, 2000).

\section{MATERIALS AND METHODS}

Field studies:

An area of about $144 \mathrm{~m}^{2}$ on the farm of Plant Protection Research Institute, Dokki, Giza Governorate, was cultivated with three cucumber 
Hassan, M. F. et al.

varieties (Zena, Thamin and Sweet crunch) during nili 2005 and summer 2006 seasons. The normal agricultural practices were undertaken without using pesticides. Throughout the two studied seasons, weekly samples of fifteen new leaves per each of the three tested replicates of every variety (45 leaves per each variety) were collected from epical leaves and examined for the different broad mite stages in two square inches per the lower leaf surface. Daily maximum, minimum temperature and daily mean relative humidity were recorded during the experimental period.

\section{Laboratory studies}

This study was carried out during 2006 summer season to determine the relationship between the broad mite P.latus populations at two levels of infestations "start and peak" and eight estimated / leaf phytochemical contents of the three studied cucumber varieties.

The samples were dried in an oven at $105 \mathrm{C}^{0}$ overnight, until a constant weight was obtained. Total nitrogen and potassium contents were determined according to the methods of AOAC, 1995; percentages of carbohydrates and total sugars according to the method of Dubois et al, 1956; reducing sugars according to Bernfeld, 1955; and non- reducing sugars were calculated by difference between the total sugars and the reducing sugars. On the other hand, the phosphorous content was determined according to the method described by David, 1966.

Data were analyzed according to SAS program (1988) which was run under WIN computer system and mean separation was conducted by using Duncan's multiple rang in this program.

\section{RESULT AND DISCUSSION}

The susceptibility of different cucumber varieties to the broad mite P.latus infestation.

Data presented in tables $(1 \& 2)$ showed the degree of infestation of three cucumber varieties with $P$.latus different stages during nili 2005 and summer 2006 seasons.

1-Eggs:

In the nili season, the mean numbers of P.latus eggs infesting leaves of cucumber varieties were 20.29, 23.77 and 25.21eggs/ inch ${ }^{2}$ for Zena, Thamin and Sweet crunch, respectively. The corresponding numbers of P.latus for the summer season were 9.36, 14.45 and 21.28eggs /inch ${ }^{2}$, respectively.

Analysis of variance of the obtained results revealed that no significance occurred between mean number of eggs/ leaf inch2 of Thamin and Sweet crunch in the nili season, while in the summer season there were significant differences between the three tested varieties, as they can be arranged in a descending order according to mite infestation to Sweet Crunch, Thamin and Zena being 21.28, 14.45 and $9.36 \mathrm{egg} / \mathrm{inch}^{2}$, respectively. 
Table (1): Susceptibility of cucumber varieties to P.latus infestation during nili season 2005 at daily mean temperature (18.2$29.7)$ and daily mean relative humidity (46.0-56.7\%).

\begin{tabular}{|l|c|c|c|c|c|c|c|c|c|}
\hline \multirow{2}{*}{$\begin{array}{c}\text { Sampling } \\
\text { date }\end{array}$} & \multicolumn{3}{|c|}{ EGG } & \multicolumn{3}{|c|}{ IMMATURES } & \multicolumn{3}{|c|}{ ADULT } \\
\cline { 2 - 10 } & Zena & Thamin & $\begin{array}{c}\text { Sweet } \\
\text { crunch }\end{array}$ & Zena & Thamin & $\begin{array}{c}\text { Sweet } \\
\text { crunch }\end{array}$ & Zena & Thamin & $\begin{array}{c}\text { Sweet } \\
\text { crunch }\end{array}$ \\
\hline $05 / 09 / 2005$ & 19.73 & 25.67 & 26.70 & 12.93 & 29.17 & 15.03 & 3.87 & 7.30 & 10.23 \\
\hline $12 / 09 / 2005$ & 36.23 & 34.57 & 34.20 & 20.40 & 35.20 & 22.60 & 4.50 & 7.03 & 13.43 \\
\hline $19 / 09 / 2005$ & 40.13 & 33.47 & 41.67 & 32.13 & 31.17 & 30.13 & 5.70 & 6.70 & 16.57 \\
\hline $26 / 09 / 2005$ & 52.67 & 38.00 & 44.87 & 43.70 & 35.57 & 50.47 & 3.60 & 7.87 & 22.27 \\
\hline $03 / 10 / 2005$ & 27.57 & 45.83 & 48.00 & 45.87 & 29.90 & 70.77 & 3.33 & 9.43 & 27.90 \\
\hline $10 / 10 / 2005$ & 16.00 & 28.93 & 21.57 & 44.90 & 21.73 & 18.40 & 2.20 & 6.27 & 7.13 \\
\hline $17 / 10 / 2005$ & 13.50 & 20.47 & 17.30 & 12.93 & 14.33 & 11.57 & 1.43 & 4.40 & 3.47 \\
\hline $24 / 10 / 2005$ & 11.17 & 19.37 & 13.20 & 8.80 & 13.13 & 14.10 & 1.80 & 3.93 & 2.20 \\
\hline $31 / 10 / 2005$ & 3.17 & 7.73 & 14.90 & 10.53 & 4.43 & 6.10 & 3.20 & 3.03 & 1.70 \\
\hline $07 / 11 / 2005$ & 2.10 & 4.97 & 11.13 & 6.13 & 2.57 & 3.23 & 4.57 & 2.57 & 1.83 \\
\hline $14 / 11 / 2005$ & 0.93 & 2.43 & 3.80 & 1.00 & 1.50 & 3.93 & 0.40 & 1.47 & 0.93 \\
\hline Mean & $20.29^{\mathrm{b}}$ & $23.77^{\mathrm{a}}$ & $25.21^{\mathrm{a}}$ & $21.76^{\mathrm{a}}$ & $19.88^{\mathrm{a}}$ & $22.39^{\mathrm{a}}$ & $3.15^{\mathrm{c}}$ & $5.45^{\mathrm{b}}$ & $9.79^{\mathrm{a}}$ \\
\hline F & \multicolumn{3}{|c|}{6.07} & \multicolumn{5}{|c|}{0.82} & \multicolumn{3}{c|}{22.06} & 2.0187 \\
\hline L.S.D & \multicolumn{3}{|c|}{2.7796} & \multicolumn{3}{|c|}{4.0556} \\
\hline
\end{tabular}

Table (2): Susceptibility of cucumber varieties to P.latus infestation during summer season 2006 at daily mean temperature (26.4-30.8) and daily mean relative humidity (44.1- 52.3\%).

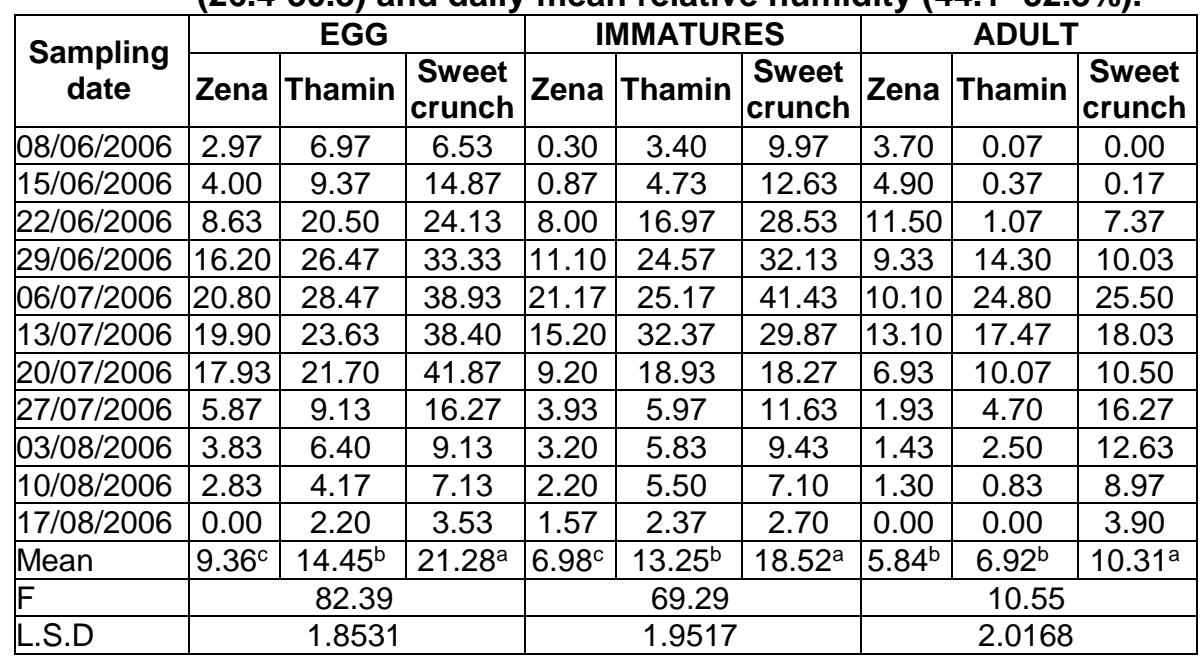

Means followed by the same letter are not significantly different at $5 \%$, based on LS.D. test.

\section{2- Immatures:}

According to the statistical analysis of the obtained data, in the nili season there were insignificant differences between the mean numbers, as they were 21.76, 19.88 and 22.39 immatures / inch ${ }^{2}$ for Zena, Thamin and Sweet crunch, respectively. On the contrary, in the summer season, there were significant differences between the obtained means, as the order of the varieties susceptibilities to the infestation of P.latus were Sweet crunch, Thamin and Zena being 18.52, 13.25 and 6.98 immatures/inch ${ }^{2}$, respectively. 
Hassan, M. F. et al.

3-Adults:

The results indicated that there were significant differences between the investigated varieties in their infestations with P.latus. In the nili season the highest infestation was observed on samples collected from Sweet crunch with mean number of 9.79 adults $/$ inch $^{2}$, while the lowest infestation was recorded on Zena being 3.15 adults $/$ inch $^{2}$, Thamin occupied the moderate infested variety, as the corresponding mean number was 5.45 adults /inch ${ }^{2}$. In the summer season, although no significant difference appeared between Thamin and Sweet crunch, yet still a significant difference occurred between Zena and each one of them, as the mean number/ leaf inch $^{2}$ was 10.31, 6.92 and 5.84 adults $/$ inch $^{2}$, for Sweet crunch, Thamin and Zena, respectively.

Thus, it is quite evident from the two studied growing seasons, cucumber variety Sweet crunch was the most susceptible to mite infestation, while Zena was tolerant, and Thamin was intermediate.

It is of interest to note that, mean numbers of eggs were nearly equal to immatures, but those of adults sharply decreased. This might be due to the transfer of pharate females carried by males to epical margin of the leaves. Moreover, white flies carried some adults to other places outside the field (Fan-YuQing et al, 1998 and Palevsky et al, 2001)

Table (3) showed that the Sweet crunch which had the highest amounts of true protein $(58.16 \%)$, phosphorous $(3.44 \mathrm{mg} / \mathrm{dl})$, total sugars $(6.07 \mathrm{~g} / 100 \mathrm{~g})$ and non- reducing sugars $(4.56 \mathrm{~g} / 100 \mathrm{~g})$ and had the lowest amount of potassium $(0.258 \mathrm{~g} / 100 \mathrm{~g})$ and total phenolic compound $(5.31 \mathrm{~g} / 100 \mathrm{~g})$, infested with the highest numbers of P.latus different stages.

On the other extreme, the least susceptible variety (Zena) contained the lowest level of true protein $(53.42 \%)$, total sugars $(2.93 \mathrm{~g} / 100 \mathrm{~g})$ and nonreducing sugars $(1.15 \mathrm{~g} / 100 \mathrm{~g})$ and the highest amount of potassium $(0.264 \mathrm{~g} / 100 \mathrm{~g})$, reducing sugars $(1.79 \mathrm{~g} / 100 \mathrm{~g})$ and total phenolic compound $(5.89 \mathrm{~g} / 100 \mathrm{~g})$. The third variety (Thamin) occupied the moderate level of infestation and their leaves contained the moderate quantity of the most tested phytochemical components.

The relationship between the population density of P.latus eggs, immatures and adults on the three tested varieties was significantly positive with true protein, but significantly negative with total hydrolysable carbohydrate, total sugars, non- reducing sugars and total phenolic compound. On the other extreme, the relationship was insignificantly negative with phosphorous and potassium elements, and insignificantly positive with reducing sugars. Nevertheless, the direction of these insignificant relationships whether positive or negative might be considered due to its constancy (repetition) in the different items.

The above mentioned results of P.latus infestation partially agree with those obtained by Pradhan, and Saha. 1997 in India who reported that there was no significant difference in N, P and K content of healthy and infested leaves of the tossa jute varieties and also in their interaction between variety and infestation. 
J. Agric. Sci. Mansoura Univ., 32 (5), May, 2007

rvvo 
However, in other phytophagous mites, (on bottle ground, cucumber, sponge gourds, ridge gourds, pumpkins and bitter gourds Sharma and Pande (1986), on sour orange Ibrahim (1988), on strawberry Luczynski et al. (1990), on maize Sawires (1992), on cucumber Ahmed (1994) and on cucumber Abou Zaid (2003)) found that the relationship between Tetranychus spp. and nitrogen and reducing sugars was positive, while it was negative with potassium, phosphorous and phenol contents.

\section{REFERENCES}

Abou Zaid, Aziza, M. M. M. 2003. Studies on some mites associated with vegetable crops. Msc. Thesis, Fac. Sci., (girls), Al -Azhar univ.167 pp.

Ahmed, A. M. 1994. Differences in susceptibility of six cucumber cultivars to infestation by Aphis gossypii Glov., Tetranychus urticae and Bemisia tabaci correlated to protein and amino acid contents of leaves. Ann. of Agric. Sci. Moshtohor, 32(4):2189-2194.

AOAC. 1995. Method of analysis. Association of official Agriculture Chemists. $16^{t}$ ed, Washington D.C. USA.

Bernfeld, P. 1955. Methods in enzymology. Acadimic press, New York, Vol.1. pp.149.

Chakraborti,-S.2000. Neem - based integrated schedule for the control of vectors causing apical leaf curling in chilli. Pest Management and Economic Zoology. 8 (1): 79-84.

David, G. 1966. Determination of organic phosphorous compounds by phosphate analysis. Methods of Biochemical analysis Vol. III, Interscience publishers Ltd. London, New York.

Dubois, M., F. Smith, K.A. Gilles, J.K. Hamilton and P.A. Rebers. 1956. Calorimetric method for determination of sugars and related substances. Anal. Chem., 28(3): 350-356.

Fan-YuQing; Petitt,-F-L. 1998. Dispersal of the broad mite, Polyphagotarsonemus latus (Acari: Tarsonemidae) on Bemisia argentifolii (Homoptera: Aleyrodidae). Experimental and Applied Acarology. 1998; 22(7): 411-415

Grinberg, M., V. Soroker, E. Palevsky, I. Shomer and R. Perl Treves. 2004. Response of cucumber to the broad mite (Polyphagotarsonemus latus). Progress in cucurbit genetics and breeding research Proceedings of Cucurbitaceae. 2004, the 8th-EUCARPIA Meeting on Cucurbit Genetics and Breeding, Olomouc, Czech Republic, 12-17 July, $2004 . \quad 319-324$

Gerson, U. (1992). Biology and control of the broad mite, Polyphagotarsonemus latus (Banks) (Acari: Tarsonemidae). Experimental and Applied Acarology, 13: 163-178.

Ibrahim, S. M. 1988. Ecological and biological studies on some predaceous mites associated with citrus trees in Egypt. Ph. D. Thesis, Fac. of Agric., Cairo univ., Egypt 148 pp.

Jeppson, L.R., Keifer, H.H. and Baker, E.W., 1975. Mites Injurious to economic plants. University of California Press, Berkeley, 614 pp. 
Luczynski, A., Isman, M. B. and Raworth, D.A. 1990. Strawberry foliar phenolics and their relationship to development of the two- spotted spider mite. J. Econ. Entom. 83:2, 557- 563.

Masoud Arbabi, Payman Namvar, Samed Karmi and Majied Farokhi. 2001. First damage record of Polyphagotarsonemus latus (Banks, 1904) (Acarina: Tarsonemidae) on potato cultivated in Jhiroft of Iran. Applied Entomology and Phytopathology.69 (1): 41- 42, 183:184.

Palevsky, E., Soroker,V., Weintraub, P., Mansour, F., Abo-Moch,F. and Gerson,U. 2001. How species- specific is the phoretic relationship between the broad mite, Polyphagotarsonemus latus (Acari: Tarsonemidae), and its insect hosts?. Experimental and Applied Acarology. 25:217-224, 2001.

Pradhan, S.K. and M.N. Saha. 1997. Effect of yellow mite (Polyphagotarsonemus latus Bank.) infestation on the major nutrient contents of tossa jute (Corchorus olitorius L.) varieties. J. Ent. Research. 1997; 21(2): 123-127

Sawires, Z.R. (1992). Susceptibility of maize varieties to mite infestation and toxicity of natural oils to mites. Egypt. J. Agri.Res. 70(1):141-148

Sharma, B.L. and D. Pande 1986. A study of relationship between the populations of Tetranychus neocalidonicus Andre (Acarina: Tetranychidae) and external characteristics of cucurbit leaves and their NPK content. J. Adv. Zool., 7 (1): 42-45.

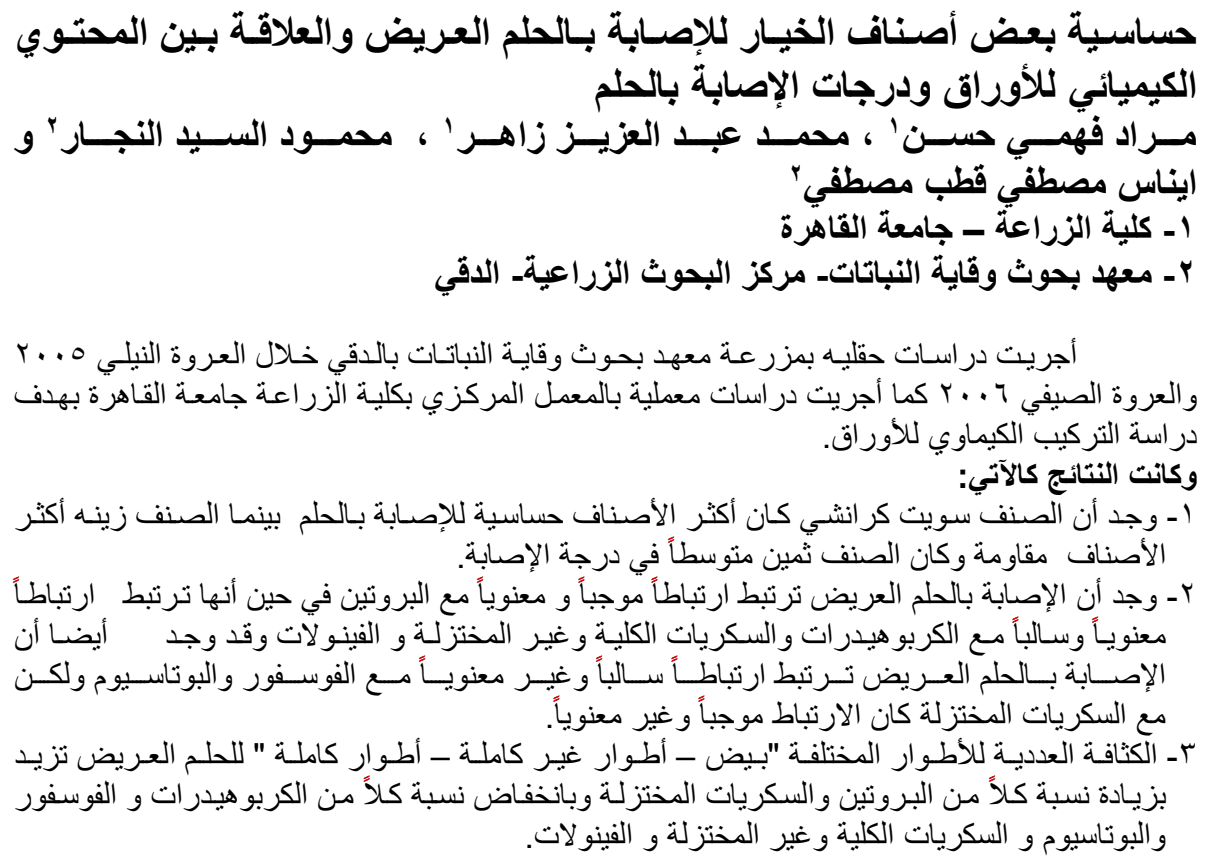


J. Agric. Sci. Mansoura Univ., 32 (5): 3771 - 3777, 2007

Table (3): Relationship between mite infestation and phytochemical components of cucumber leaves

\begin{tabular}{|c|c|c|c|c|c|c|c|c|c|c|c|}
\hline \multirow[b]{2}{*}{ variety } & \multirow{2}{*}{\multicolumn{2}{|c|}{ stages }} & \multicolumn{9}{|c|}{ Phytochemical components (\%) } \\
\hline & & & mean & $\begin{array}{c}\text { True } \\
\text { Protein } \%\end{array}$ & $\underset{(\mathrm{mg} / \mathrm{dL})}{\mathbf{P}}$ & $\begin{array}{c}K \\
(g / 100 g)\end{array}$ & $\begin{array}{c}\text { Total } \\
\text { Hydrolysable } \\
\text { Carbohydrate } \\
(\mathbf{g} / 100 \mathrm{~g})\end{array}$ & $\begin{array}{l}\text { T.Soluble } \\
\text { Sugars } \\
(\mathrm{g} / 100 \mathrm{~g})\end{array}$ & $\begin{array}{l}\text { Reducing } \\
\text { Sugars } \\
(\mathrm{g} / 100 \mathrm{~g})\end{array}$ & \begin{tabular}{|c} 
Non \\
Reducing \\
Sugars \\
(g/100g)
\end{tabular} & $\begin{array}{c}\text { T. phenolic } \\
\text { Compound } \\
(\mathrm{g} / 100 \mathrm{~g})\end{array}$ \\
\hline \multirow{4}{*}{ Zena } & & & mean & $53.424^{a}$ & $3.235^{a}$ & $0.264^{a}$ & $14.59^{b}$ & $2.925^{\mathrm{b}}$ & $1.786^{\mathrm{a}}$ & $1.15^{b}$ & $5.895^{\mathrm{a}}$ \\
\hline & $\begin{array}{l}\infty \\
\frac{1}{\sigma}\end{array}$ & Eggs & & $0.851^{*}$ & -0.514 & -0.781 & $-0.893^{* *}$ & -0.660 & -0.390 & -0.734 & -0.584 \\
\hline & $\Xi$ & Immatures & & $0.848^{*}$ & -0.481 & $-0.839 *$ & $-.9102^{\star *}$ & -0.696 & -0.393 & -0.785 & -0.570 \\
\hline & & Adults & & 0.716 & -0.532 & -0.880 & -0.888 & -0.709 & -0.452 & -0.767 & -0.457 \\
\hline \multirow{4}{*}{ Thamin } & & & mean & $52.855^{\mathrm{a}}$ & $3.005^{a}$ & $0.262^{\mathrm{a}}$ & $15.91^{\mathrm{a}}$ & $4.365^{\mathrm{ab}}$ & $1.335^{\mathrm{a}}$ & $3.03^{a}$ & $5.735^{\mathrm{a}}$ \\
\hline & $\begin{array}{l}\mathscr{\Phi} \\
\frac{\Phi}{\sigma}\end{array}$ & Eggs & & $0.921^{* *}$ & -0.739 & -0.696 & $-0.935^{\star *}$ & $-0.795^{\star}$ & 0.427 & $-0.832^{*}$ & $-0.931^{* *}$ \\
\hline & \pm & Immatures & & $0.839^{*}$ & $-0.823^{*}$ & -0.747 & $-0.932^{* *}$ & $-0.815^{*}$ & 0.237 & $-0.820^{*}$ & $-0.81^{*}$ \\
\hline & & Adults & & $0.927^{\star \star}$ & $-0.805^{\star}$ & -0.772 & $-0.972^{\star \star}$ & $-0.832^{*}$ & 0.477 & $-0.876^{*}$ & $-0.937^{\star \star}$ \\
\hline \multirow{4}{*}{$\begin{array}{l}\text { Sweet } \\
\text { crunch }\end{array}$} & & & mean & $58.157^{a}$ & $3.439^{a}$ & $0.258^{a}$ & $14.99^{\mathrm{ab}}$ & $6.065^{a}$ & $1.505^{\mathrm{a}}$ & $4.56^{a}$ & $5.305^{a}$ \\
\hline & & Eggs & & $0.977^{\star \star \star}$ & -0.251 & -0.683 & $-0.979^{\star \star \star}$ & $-0.949^{\star *}$ & 0.370 & $-0.984^{\star \star \star}$ & $-0.928^{\star \star}$ \\
\hline & $\frac{\stackrel{\varrho}{\sigma}}{\frac{\pi}{\supset}}$ & Immatures & & $0.978^{* \star *}$ & -0.210 & -0.677 & $-0.977^{* * *}$ & $-0.936^{\star *}$ & 0.394 & $-0.975^{\star \star \star}$ & $-0.945^{\star *}$ \\
\hline & $=$ & Adults & & $0.969^{\star \star \star}$ & -0.250 & -0.705 & $-0.978^{* * *}$ & $-0.949^{* *}$ & 0.372 & $-0.984^{\star \star \star}$ & $-0.929^{\star \star}$ \\
\hline
\end{tabular}

Means followed by the same letter are not significantly different at $5 \%$, based on L.S.D. test 
J. Agric. Sci. Mansoura Univ., 32 (5), May, 2007

3771377237733774377537763777 